\title{
Analysis of non-standard MiG-29 engine start procedures
}

\author{
The paper describes alternative start procedures if regular MiG-29 engine start procedures are disturbed. The work \\ presents ground engine start procedures with a turbine starter and an automatic start of both engines. A procedure \\ algorithm has been presented in case malfunctions are detected depending on the level of the malfunction complexity. \\ Example results have been included that come from the flight operating parameters recorder showing the versatility of \\ events that may occur when starting the MiG-29 engines.
}

Key words: turbine engine, engine start, engine malfunctions

\section{Analiza niestandardowych procedur uruchamiania silników samolotu MiG-29}

W artykule opisano metodykę postępowania w sytuacji zakłóceń normalnych procedur uruchamiania silników samolotu MiG-29. Przedstawiono w nim uruchamianie silników na ziemi za pomoca rozrusznika turbinowego oraz uruchamianie automatyczne obu silników samolotu. Zaprezentowano algorytm postępowania przy wykryciu awarii w zależności od stopnia jej skomplikowania. Zamieszczono także przykładowe wyniki pochodząe z rejestratora parametrów eksploatacyjnych samolotów, obrazujące różnorodność niepożadanych zdarzeń, które moga wystapić podczas uruchomienia silników samolotu MiG-29.

Słowa kluczowe: silnik turbinowy, uruchomienie silnika, awarie silnika

\section{Introduction}

The advancement of aviation, construed as crossing one of the uncrossable boundaries for humans, initially continued in two independent directions. The first direction were aircraft lifted by buoyancy described in the Archimedes law otherwise known as aerostats. Aerostats include balloons and airships. The other direction were aircraft capable of flying thanks to aerodynamic force generated by dynamic interaction of air and stationary or movable airfoils. Aerodynes with stationary airfoils include airplanes, gliders, hang gliders and paragliders while aerodynes with movable airfoils include helicopters, gyroplanes (rotating airfoils) and ornithopters. The first successful attempt to fly with an aircraft lighter than air took place already in the XVIII century. Aerostats and their hybrids - statodynes were a great success of aviation until the WWI when the progress in aviation weapons slowed their development because they were more susceptible to gunfire than aerodynes. Among aircraft operating because of dynamic interaction with air, the greatest advancement took place in propelled aerodynes: airplanes, rotorcrafts and ornithopetrs.

Planes have propulsion systems of a varied level of complexity and different principle of operation, which decide about its performance. Advancement of propulsion systems forces a development of new type of engines - starting from piston and jet engines ending with turbojet and turboprops. Today, five basic types of engines are used in aviation: piston, turbine, jet, turboprop, ramjet and rocket. The advancement of turbine jet engines that are discussed in this paper, aimed at maximizing the thrust by using afterburners or increasing the efficiency by applying fans in turbofan versions of the engines. The fundamental aim of a propulsion system is to

\section{Wprowadzenie}

Rozwój lotów nad powierzchnią ziemi, rozumianych jako przekraczanie jednej z nieosiągalnych przez człowieka granic, początkowo odbywał się w dwóch niezależnych kierunkach. Pierwszy z nich obejmował loty statkami powietrznymi, unoszącymi się w powietrzu dzięki sile wyporu opisanej przez prawo Archimedesa, nazywanych aerostatami. Do aerostatów zalicza się balony i sterowce. Drugi z kierunków dotyczy statków powietrznych utrzymujących się w powietrzu dzięki sile nośnej, powstającej przez dynamiczne oddziaływanie powietrza na nieruchome lub ruchome płaty nośne. Do aerodyn z nieruchomymi płatami nośnymi zalicza się samoloty, szybowce, lotnie i paralotnie, natomiast do aerodyn z ruchomymi płatami nośnymi należą śmigłowce i wiatrakowce wyposażone w wirujące płaty nośne oraz skrzydłowce. Już w XVIII wieku doszło do pierwszej udanej próby lotu statkiem lżejszym od powietrza. Konstrukcje aerostatów oraz ich hybryd, statodyn, były sukcesem lotnictwa do I Wojny Światowej, kiedy to postęp w dziedzinie broni przeciwlotniczej zahamował ich rozwój jako obiektów podatniejszych na ostrzał niż aerodyny. Wśród statków powietrznych utrzymujących się w atmosferze na skutek dynamicznego oddziaływania powietrza największy rozwój dotyczy aerodyn z napędem: przede wszystkim samolotów, ale także wiropłatów i skrzydłowców.

Każdy samolot wyposażony jest w zespół napędowy, o różnym stopniu złożoności i różnej zasadzie funkcjonowania, który decyduje o jego osiągach. Rozwój systemów napędowych wiąże się z rozwojem nowych rodzajów silników - począwszy od silników tłokowych przez odrzutowe do turboodrzutowych i turbośmigłowych. Współcześnie w lotnictwie występuje pięć podstawowych rodzajów silni- 
provide thrust necessary for a plane to perform its task [8, 9] in the entire operating range, at all altitudes airspeeds and g-loads. During the operation of an aircraft, it is necessary to provide stable operation of the propulsion system. Abrupt changes during the flight result in the occurrence of variable engine loads that are variable in time and, which exposes the engine as the main part of the aircraft to destructive forces. This is particularly the case during combat flights.

\section{Analysis of malfunction states}

Safe operation in aviation is fundamental for the success of any entity using aircraft as a tool for its operation. Safe operation is a complex issue and is influenced by a variety of factors resulting from concentration of multiple systems and connections of these systems in a relatively small space, which is necessary for a plane to function properly. Safety of a technological product is its ability to remain within the risk range not greater than the criterion value under assumed conditions of operation [11]. In aviation, criterion values are commonly applied in relation to aircraft service life. A modern turbojet engine can be operated for 40 years, but its service interval, if continuously operated, must not exceed 18 months. The greatest risk for a jet plane is improper operation of its aggregates and functional assemblies. The first direction regarding safety in aviation is related to a systematic approach already on the design stage:

- application of modern constructions and technologies,

- application of modern high quality construction materials,

- validation of assumptions through object testing,

- validation of proper prototype operation.

As regards aircraft operators, safety is ensured through appropriate selection of candidates for the profession, education and trainings, motivation, maintaining mental stamina etc. Another direction in the development of safety is related to the evaluation of systems at all stages of their existence through methods and criterions applicable for the subsequently evaluated stages. The paper discusses the second direction related to safety issues, particularly the procedures in case of aircraft malfunction. It determines the procedures for elimination of malfunctions (with examples). The available means enabling the identification of the reasons for a malfunction are [2]: technical know-how and personnel expertise, SIL (Aviation Engineering Services), data from the on-board recorders, technical documentation (manuals, bulletins, schematics etc.), tools, measurement equipment and diagnostic stands.

If an aircraft malfunction occurs, the methodology depends on the level of the malfunction complexity. Three methods have been distinguished: method I (single aircraft) - when the technician's knowledge is sufficient to remedy the problem; method II (flight) - when the knowledge of a technician and the flight commander is necessary and method III (squadron) - when the elimination of a malfunction requires the knowledge of a senior squadron technician or its commander. Figure 1 shows decision-making schematics that, together with the schematics in Fig. 2, have been developed by the authors based on the guidelines contained in manuals [3-6]. ków: łłokowe, turbinowe odrzutowe, turbinowe śmigłowe, strumieniowe i rakietowe. Rozwój silników turbinowych odrzutowych, o których będzie mowa w artykule, ukierunkowany był na zwiększanie ciągu maksymalnego przez użycie dopalaczy lub zwiększenie sprawności przez zastosowanie wentylatorów w silnikach wielostrumieniowych. Podstawowym zadaniem zespołu napędowego samolotu jest zapewnienie ciągu niezbędnego do realizacji stawianych przed samolotem zadań [8, 9], w całym zakresie eksploatacyjnym, wysokości, prędkości lotu oraz przeciążeń. Podczas eksploatacji samolotu bardzo ważne jest zapewnienie stabilnej pracy zespołu napędowego. Gwałtowne zmiany w locie powodują wystąpienie zmiennych w czasie, dodatkowych obciążeń silników, które jako główne części samolotu narażone są w locie manewrowym na dodatkowe obciążenia niszczące. Jest to szczególnie istotne podczas wykonywania manewrów bojowych.

\section{Analiza stanów awaryjnych}

Bezpieczna eksploatacja techniki lotniczej jest jednym z najistotniejszych czynników właściwego funkcjonowania każdej instytucji wykorzystującej statki powietrzne jako narzędzia swego działania. Jest to zagadnienie złożone i jest ono rezultatem wielu czynników, które wynikają z nagromadzenia na względnie małej przestrzeni bardzo dużej liczby systemów i połączeń integrujących te systemy, co jest niezbędne do właściwego funkcjonowania samolotu jako całości. Bezpieczeństwo wytworu techniki jest to zdolność tego wytworu, w założonych warunkach eksploatacji, do pozostawania w stanie ryzyka nie większego niż wartość kryterialna [11]. W lotnictwie powszechnie stosowane są wartości kryterialne w odniesieniu do okresu eksploatacji statku powietrznego. Nowoczesny silnik turboodrzutowy może być eksploatowany do 40 lat, ale jego resurs wynosi 18 miesięcy nieustannej pracy. Największym zagrożeniem samolotu odrzutowego jest niewłaściwe działanie agregatów i zespołów funkcjonalnych, będących na jego wyposażeniu. Pierwszy kierunek dotyczący bezpieczeństwa, w odniesieniu do techniki lotniczej, wiąże się z systemowym podejściem na etapie projektowania:

- wykorzystanie nowoczesnych konstrukcji i technologii,

- wykorzystanie nowoczesnych materiałów konstrukcyjnych o wysokiej jakości,

- weryfikacja założeń podczas badań obiektów,

- weryfikacja prawidłowej eksploatacji prototypu.

W odniesieniu natomiast do operatorów realizowany jest on przez odpowiedni dobór kandydatów do zawodu, kształcenie i treningi, motywowanie, podtrzymywanie kondycji psychicznej itp. Drugi kierunek rozwoju bezpieczeństwa wiąże się z oceną systemów, we wszystkich fazach ich istnienia, za pomocą metod i kryteriów przydatnych odpowiednio do kolejno ocenianych faz. W artykule zaprezentowano drugi kierunek problematyki bezpieczeństwa, a w szczególności postępowanie w sytuacji zaistnienia niesprawności statku powietrznego. Określono zasady postępowania przy usuwaniu niesprawności wraz z przykładami. Dostępnymi środkami umożliwiającymi wykrycie przyczyn niesprawności sprzętu lotniczego są [2]: wiedza techniczna i doświadczenie per- 


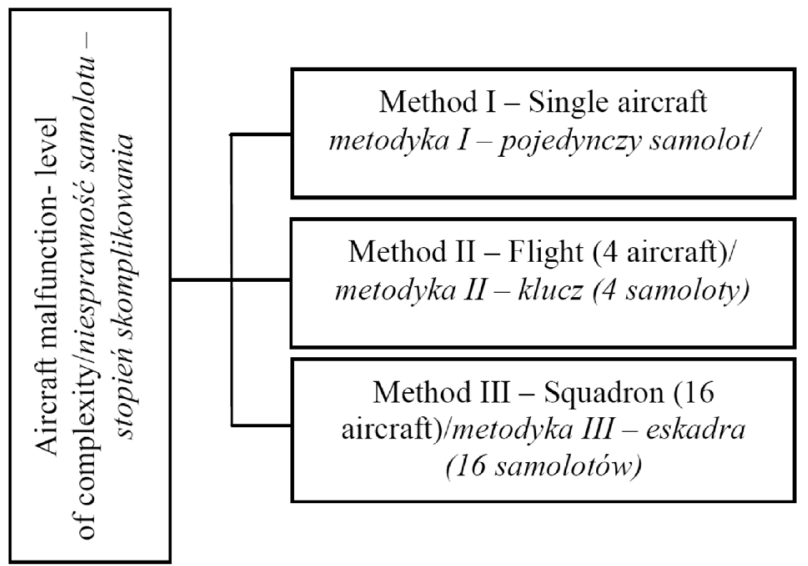

Fig. 1. Decision making schematics depending on the malfunction complexity

Rys. 1. Schemat decyzyjny zależny od stopnia złożoności wykrytej awarii

The above-given methods share a common algorithm that has been shown in a diagram in Fig. 2. The fundamental difference is the way and scope of the malfunction analysis.

In a situation in which method I applies, the following suffice: a recall of recent malfunctions of an aircraft, the analysis of the possible cause and effect relation of the current malfunction with the previous ones, evaluation of the reason for the malfunctions and the possibility of its elimination as well as proactive behavior.

If method II applies, the analysis of the malfunction conditions is based on:

- determining of the operating conditions and circumstances of the malfunction occurrence,

- recall of recent malfunctions related to the aircraft operated in a flight,

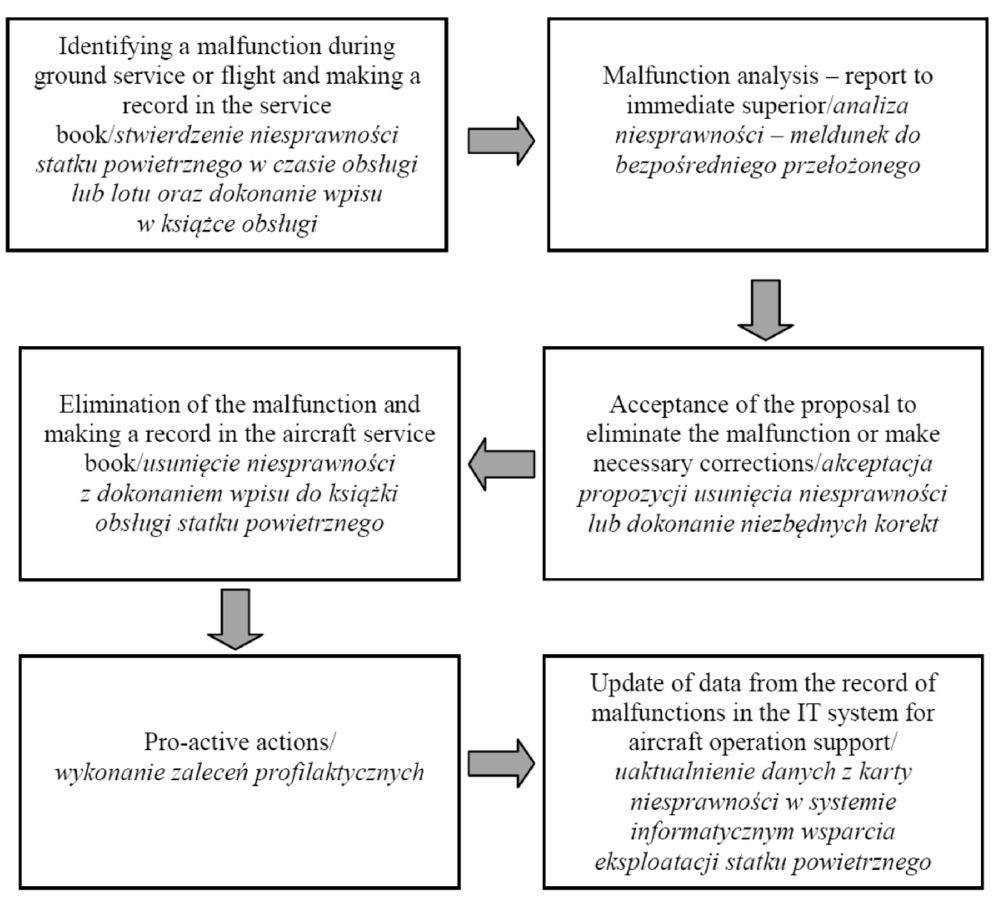

Fig. 2. Algorithm of malfunction detection

Rys. 2. Algorytm postępowania przy wykryciu awarii sonelu latającego oraz SIL (Służba Inżynieryjno-Lotnicza), dane z pokładowych urządzeń rejestrujących, dokumentacja techniczna (instrukcje, biuletyny, schematy itp.), narzędzia i aparatura kontrolno-pomiarowa, stanowiska diagnostyczne.

Przy wystąpieniu niesprawności statku powietrznego metodyka postępowania przy jej usuwaniu zależy od stopnia skomplikowania tej niesprawności. Przyjęto, że występują trzy metodyki postępowania: metodyka I (pojedynczy samolot) - gdy wystarczy wiedza technika samolotu, aby niesprawność została usunięta; metodyka II (klucz) - gdy niezbędna jest wiedza i doświadczenie technika lub dowódcy klucza oraz metodyka III (eskadra) - gdy do jej usunięcia potrzebny jest starszy technik eskadry bądź jej dowódca. Na rysunku 1 pokazano schemat decyzyjny, który wraz ze schematem $z$ rys. 2 został opracowany przez autorów na podstawie wytycznych zawartych w instrukcjach [3-6].

Podane metodyki charakteryzuje wspólny algorytm postępowania, który przedstawiono na schemacie blokowym - rys. 2. Zasadniczą różnicą jest sposób i zakres prowadzenia analizy niesprawności.

W sytuacji, gdy ma zastosowanie metodyka I wystarczy przypomnienie niesprawności statku powietrznego zaistniałych w ostatnim okresie, analiza ewentualnego związku przyczynowego rozpatrywanej niesprawności z poprzednio występującymi, ocena przyczyny powstania i możliwości usunięcia niesprawności oraz propozycje działań profilaktycznych. Gdy jest stosowana metodyka II, analiza niesprawności polega między innymi na:

- określeniu warunków pracy i okoliczności, podczas których zaistniała niesprawność,

- przypomnieniu niesprawności zaistniałych w ostatnim okresie na samolotach eksploatowanych w kluczu,

- analizie ewentualnego związku przyczynowego rozpatrywanej niesprawności z poprzednio występującymi na samolotach eksploatowanych w kluczu oraz szukanie podobieństw do niesprawności ze znanymi z informacji z biuletynów informacyjnych, telegramów, opracowaniu planu lokalizacji niesprawności i jej usunięcia,

- $\quad$ ustaleniu przyczyn niesprawności, sprawdzeniu, czy podobne niesprawności nie występują na innych samolotach eksploatowanych w kluczu oraz opracowaniu propozycji przedsięwzięć profilaktycznych.

Przy zastosowaniu metodyki III zakres prowadzonej analizy jest prawie zbliżony do występującego przy metodyce II, jednak dotyczy samolotów i występujących na nich niesprawności w odniesieniu do eskadry. Jeżeli wszystkie możliwości wynikające $\mathrm{z}$ algorytmu postępowania dla metodyki I zostają wyczerpane i nie można usunąć niesprawności, to trzeba wykonać czynności zgodnie z metodyką II, a jeśli nadal nie można usunąć niesprawności, to $\mathrm{w}$ następnym etapie postępuje się zgodnie $\mathrm{z}$ metodyką III. 

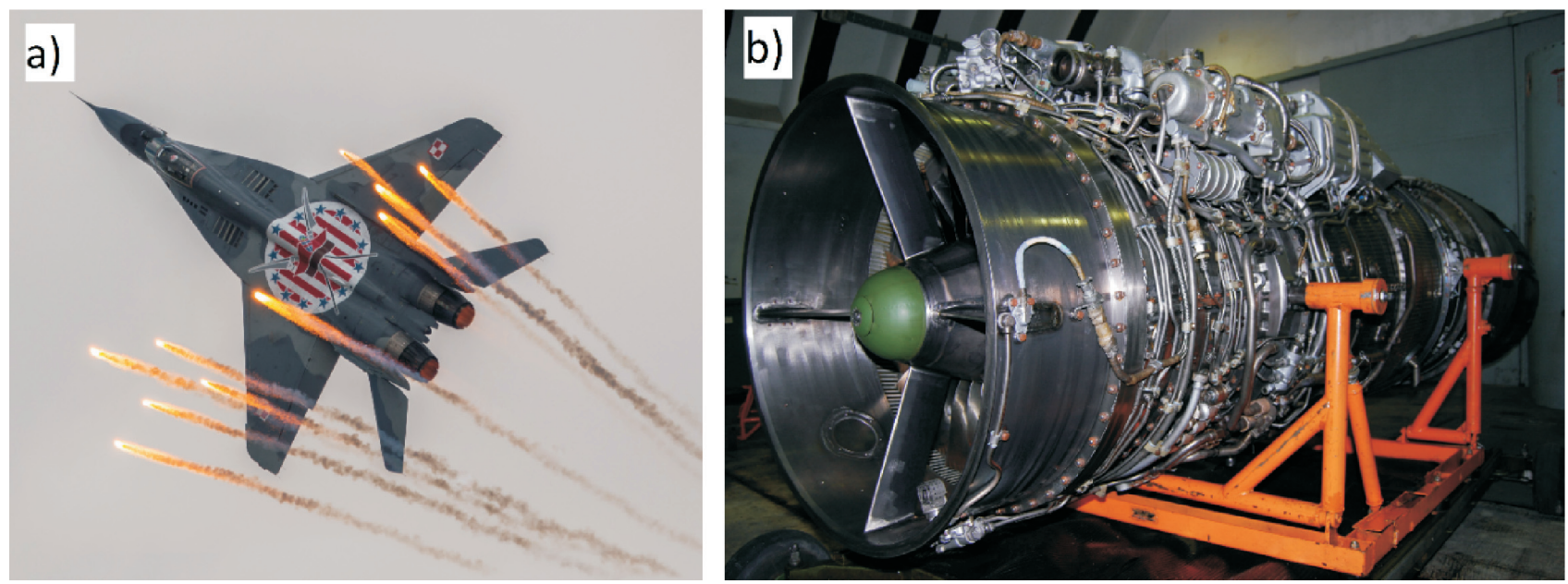

Fig. 3. Research objects: a) MiG-29, b) RD-33 engine (images by authors)

Rys. 3. Obiekty badań: a) samolot MiG-29, b) silnik RD-33 (zdj. autorów)

- analysis of possible cause and effect relation between the current malfunction with the previous ones in aircraft operated in a flight and search for similarities to other malfunctions described in bulletins,

- development of a plan how to identify the malfunction and eliminate it,

- determining the reason for the malfunction,

- checking whether similar malfunctions occur in other planes operated in a flight and developing proposals of proactive behavior.

If method III applies, the scope of analysis is almost like in method II but it is related to the aircraft (its malfunctions) of the entire squadron. If algorithm for method I is used and the malfunction cannot be eliminated, actions according to method II are to be taken and if that is unsuccessful, method II is to be applied.

\section{Description of the research object}

MiG-29 is a lightweight, high maneuverability supersonic fighter plane designed in an aerodynamic system of wings and fuselage as a single aerodynamic area. The aircraft is fitted in two RD-33 turbofan engines with afterburners. Figure 3 presents MiG-29 and one of the RD-33 engines.

The components of the RD-33 engine are [3]:

- low pressure rotor (LPR) with an axial four-stage fan and an air-cooled single stage axial turbine (nozzle system and turbine vanes),

- high pressure rotor (HPR) with an axial nine-stage compressor and an air-cooled single stage turbine (variable geometry vanes of the first two stages are adjusted depending on the angle of inclination),

- annular combustor with fuel injectors located in the general collector,

- afterburner chamber with flow mixing upstream of the afterburner,

- ultrasound outlet nozzle with smooth adjustment of critical and outlet flow,

- aggregate transfer case from the high pressure rotor,

\section{Opis obiektu badań}

Samolot MiG-29 jest lekkim, wysokomanewrowym, naddźwiękowym samolotem myśliwskim, który został skonstruowany w układzie aerodynamicznym, stanowiącym połączenie skrzydeł i kadłuba w jedną powierzchnię nośną. Zespół napędowy samolotu stanowią dwa turboodrzutowe, dwuprzepływowe silniki RD-33 z dopalaczami. Na rysunku 3 przedstawiono samolot MiG-29 oraz zdemontowany jeden z jego silników RD-33.

Elementami składowymi silnika RD-33 są [3]:

- wirnik niskiego ciśnienia (WNC) z osiowym czterostopniowym wentylatorem i jednostopniową turbiną osiową, chłodzoną powietrzem (aparat dyszowy i łopatki turbiny),

- wirnik wysokiego ciśnienia (WWC) z osiową dziewięciostopniową sprężarką i jednostopniową turbiną, chłodzoną powietrzem (łopatki kierownicze pierwszych dwóch stopni sprężarki są regulowane w zależności od kąta natarcia),

- pierścieniowa komora spalania z wtryskiwaczami paliwa, znajdującymi się na ogólnym kolektorze,

- komora dopalacza ze wstępnym mieszaniem przepływów przed kolektorem dopalacza,

- naddźwiękowa dysza wylotowa z płynną regulacją przepływu krytycznego i wylotowego,

- skrzynka napędu agregatów silnika z napędem od wirnika wysokiego ciśnienia,

- układ automatycznej regulacji i sterowania silnikiem wraz z układem uruchamiania,

- instalacje: olejowa, poboru powietrza, kontroli parametrów pracy silnika.

\section{Procedura rozruchu silników}

Zespół napędowy samolotu na ziemi uruchamia się za pomocą rozrusznika turbinowego [1], przekazującego napęd na silniki za pomocą skrzynki napędu agregatów. Układ uruchamiania zespołu napędowego zapewnia:

- oddzielne uruchamianie silników na lotnisku w dowolnej kolejności,

- następne uruchomienie dwóch silników, 
- engine and starter automatic adjustment and control,

- systems: oil feed, air intake, parameter control.

\section{Engine start procedure}

The engines of the aircraft are started on the ground with a turbine starter [1] transferring power to the engine through the transfer case. The engine starter system ensures:

- separate start of both engines in the airstrip in any sequence,

- sequential start of two engines,

- engine cold start and start of the turbine starter,

- automatic, semi-automatic or manual start of the engine in the air,

- backup start sequence while launching missiles or firing a gun.

The ground engine start continues as follows [3]: upon depressing of the GND START button the turbine starter begins to operate and the engine ignition system turns on. LH or RH ENGINE START light begins to flash. The clutch of the turbine starter engages and the turbine starter transfers the power to the rotor of the high-pressure compressor. At the HPR speed of $35 \%$, the ignition automatics deactivates and the ENGINE START light stops flashing. At the HPR speed of $50 \%$ the turbine starter disengages. Sequential automatic start of two engines is done in the following manner: the start switch is in START BOTH position while the DSS controls are in the minimum engine speed position and the GND START is depressed. The engines will start automatically. Through the aggregate transfer case, the turbine starter drives the right engine first ensuring its start and speed of HPR at least $50 \%$. Upon reception of a signal from the right engine $\mathrm{n} \geq 50 \%$ the turbine starter switches off for $10 \mathrm{~s}$ in order to avoid harsh starter clutch engagement with the left engine. After $10 \mathrm{~s}$, the start of the left engine begins and the turbine starter works until the engine reaches $n \geq 50 \%$.

\section{Analysis of malfunction states of the MiG-29 engines}

The graphs presented in Figs. 4-6 were obtained from THETYS IV- an automatic recorder of flight parameters. The graphs present the courses of: $\alpha$ DSSp - DSS position for the right engine, $\alpha \mathrm{DSS} 1$-DSS position for the left engine, $\mathrm{nZp}$ - compressor speed of the right engine, $\mathrm{nZl}$ - compressor speed of the left engine, UPst - direct current voltage. The quantities given in the lower part of the figures are one-off commands that are not related to the discussed situations.

Figure 4 presents the course of the engine start during which a malfunction occurred. Despite average malfunction complexity, method I was applied for its elimination (method used for relatively simple malfunctions). This resulted from the fact that the analysis of the situation was taken care of by personnel with extensive experience and knowledge. During the engine start in the automatic mode, the start of the left engine was unsuccessful after the start of the right one; the reading of the left engine tachometer was zero - the start procedure was aborted.

When analyzing the recording from the OFC (Objective flight control) of an unsuccessful engine start, we can
- zimny rozruch silników i rozrusznika turbinowego,

- automatyczne, półautomatyczne lub ręczne uruchomienie silników w powietrzu,

- rozruch wyprzedzający w powietrzu podczas odpalania pocisków rakietowych lub strzelania z działka.

Uruchomienie silnika na ziemi przebiega w następujący sposób [3]: po naciśnięciu przycisku uruchomienia GND START uruchamia się rozrusznik turbinowy i włącza układ zapłonu silnika. Świeci się wtedy lampka sygnalizacyjna: uruchomienie lewego lub prawego silnika LH (RH) ENGINE START. Sprzęgło rozrusznika turbinowego łączy się z uruchamianym silnikiem, po czym rozrusznik turbinowy napędza wirnik sprężarki wysokiego ciśnienia. Przy prędkości obrotowej WWC 35\% wyłącza się automat zapłonowy, gaśnie przy tym lampka uruchomienia silnika, a przy prędkości obrotowej WWC 50\% rozrusznik turbinowy odłącza się. Kolejne automatyczne uruchomienie dwóch silników wykonuje się w następujący sposób: przełącznik zakresu uruchomienia jest w położeniu start dwóch START BOTH; przy dźwigniach sterowania silnikami (DSS) w położeniu odpowiadającym minimalnej prędkości obrotowej oraz naciśnięciu przycisku GND START silniki uruchamiają się automatycznie. Rozrusznik turbinowy przez skrzynkę napędu agregatów napędza początkowo prawy silnik, zapewniając jego uruchomienie i osiągnięcie prędkości obrotowej wału silnika WWC nie mniejszej niż 50\%. Po otrzymaniu z bloku komend granicznych prawego silnika sygnału $\mathrm{n} \geq 50 \%$ rozrusznik turbinowy wyłącza się na $10 \mathrm{~s}$, aby zapobiec uderzeniowemu połączeniu się sprzęgła rozrusznika turbinowego z wałem lewego silnika. Po $10 \mathrm{~s}$ następuje uruchomienie lewego silnika, przy czym rozrusznik turbinowy pracuje do osiągnięcia przez ten silnik $\mathrm{n} \geq 50 \%$.

\section{Analiza stanów awaryjnych zespołu napędowego MiG-29}

Przedstawione na rys. 4-6 wykresy uzyskano z automatycznego rejestratora parametrów lotu THETYS IV. Wykresy przedstawiają przebiegi: $\alpha$ DSSp - położenie DSS silnika prawego, $\alpha \mathrm{DSS} 1$ - położenie DSS silnika lewego, nZp obroty sprężarki silnika prawego, nZl - obroty sprężarki silnika lewego, UPst - napięcie prądu stałego. Wielkości podane w dolnej części kolumny z prawej strony rysunków są to tzw. komendy jednorazowe, które nie wiążą się z omawianymi sytuacjami. Na rysunku 4 przedstawiono przebieg rozruchu silnika, podczas którego doszło do awarii. Mimo średniej złożoności niesprawności, do jej usunięcia zastosowano metodykę I (przeznaczoną do nieskomplikowanych niesprawności). Wynikało to $\mathrm{z}$ tego, że analizą sytuacji zajmował się personel z dużym doświadczeniem i wiedzą. Podczas uruchamiania silnika w trybie automatycznym, po uruchomieniu silnika prawego nie nastąpiło uruchomienie lewego, pilot stwierdził brak wskazań prędkości obrotowej wału lewego silnika - rozruch przerwano.

Analizując zapis materiałów OKL (Obiektywna Kontrola Lotów) nieudanego uruchomienia silnika, można zauważyć moment, w którym uruchomił się silnik lewy. Lina żółta przedstawia prędkość obrotową wału silnika lewego, który 
see a moment when the left engine starts. The yellow line denotes the speed of the left engine reaching the desired level while the blue line represents the right engine. Upon the pilot's signal that the right engine did not reach the desired speed, the operation was aborted. Following the inspection, a malfunction of the Automatic Engine Starter (AES) was identified. The component was renewed.

Complex malfunctions are eliminated in accordance with method

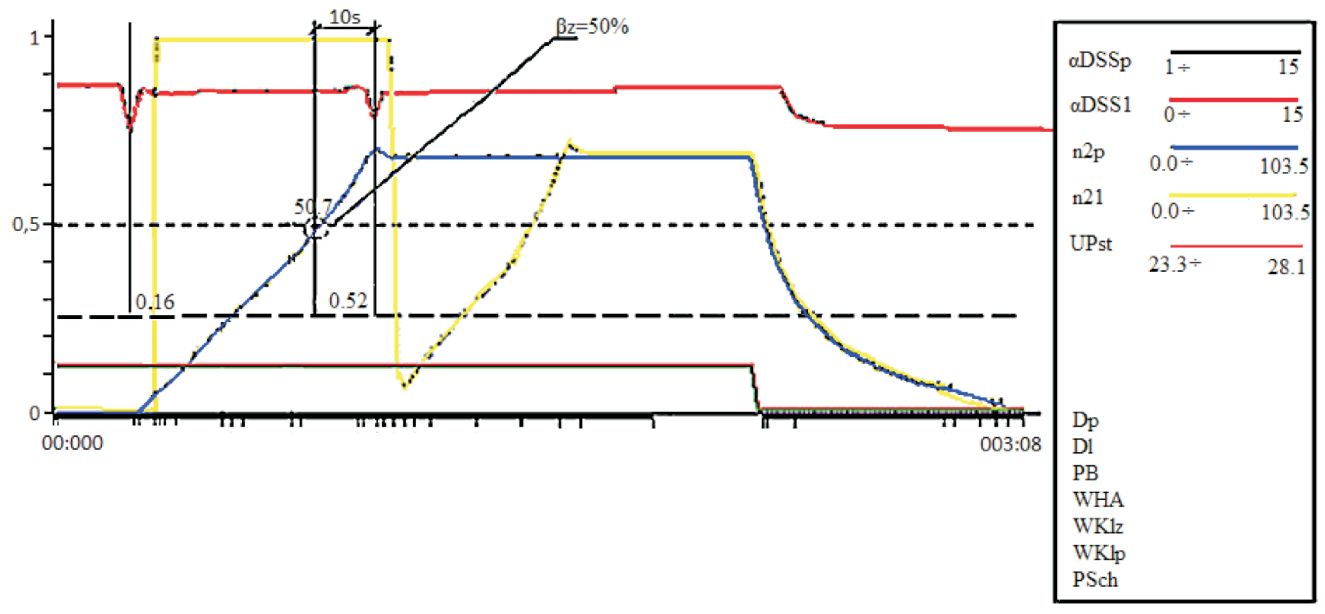

III. Figure 5 presents an uncontrolled change of engine speed that should remain inactive during the trial. The complexity and non-typical nature of malfunctions requires knowledge of the most experienced personnel and simultaneous multiaspect analyses. An extended analysis based on identification of several possible causes of the malfunction allowed the identification of the actual cause of the failure. During the engine start, a simultaneous uncontrolled rev-up of both engines occurred.

The setting of the switches in the cockpit was correct (left DSS in the MG position /IDLE/, right DSS in the STOP position). The duration of the speed increase procedure lasted for approx. $25 \mathrm{~s}$ and then the engine speeds n2lew (yellow) and n2praw (blue) reached approx. 13\% (state C). An analysis was performed leading to a conclusion that the reason for the malfunction might have been a faulty AES.

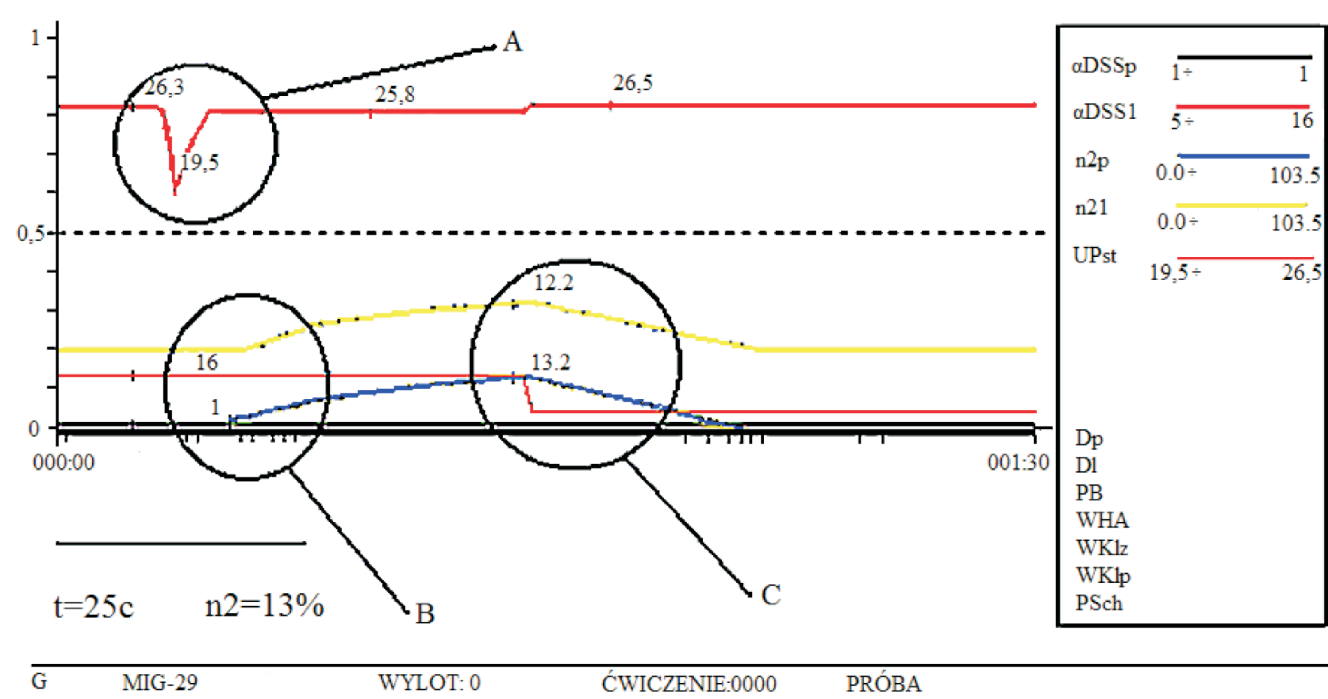

Fig. 5. Uncontrolled rev-up of one of the MiG-29 engines

Rys. 5. Niekontrolowane zwiększenie prędkości obrotowej jednego z silników samolotu MiG-29 osiągnął oczekiwany poziom, a linia niebieska - silnika prawego. Po zasygnalizowaniu przez pilota braku oczekiwanej prędkości obrotowej wału silnika prawego nastąpiło ich wyłączenie. W wyniku przeprowadzonych kontroli stwierdzano niesprawność agregatu rozruchowego APD (z ros. Automatyczny Rozrusznik Silnika), który został zamieniony.

Skomplikowane niesprawności usuwane są zgodnie z metodyką III. Na rysunku 5 przedstawiono niekontrolowaną zmianę prędkości obrotowej silnika, który podczas próby powinien pozostać nieruchomy. Złożoność oraz nietypowość niesprawności wymusza zaangażowanie najbardziej doświadczonego personelu i analizowanie niesprawności równolegle na kilku płaszczyznach. Rozszerzona analiza oparta na weryfikacji kilku z możliwych przyczyn zaistnienia niesprawności pozwoliła na wskazanie rzeczywistej przyczyny awarii. Podczas rozruchu silnika lewego nastąpiło jednoczesne niekontrolowane zwiększenie prędkości obrotowej obu silników.

Ustawienie przełączników w kabinie było prawidłowe, DSS lewy w płożeniu MG (mały gaz, zwany IDLE), DSS prawy w położeniu STOP. Czas zwiększania prędkości obrotowej wynosił ok. $25 \mathrm{~s}$ i po tym czasie prędkości obrotowe wału n2lew (kolor żółty) i n2praw (kolor niebieski) osiągnęły około 13\% (stan C). Przeprowadzono analizę, w wyniku której ustalono, że powodem mogło być nieprawidłowe działanie APD. 


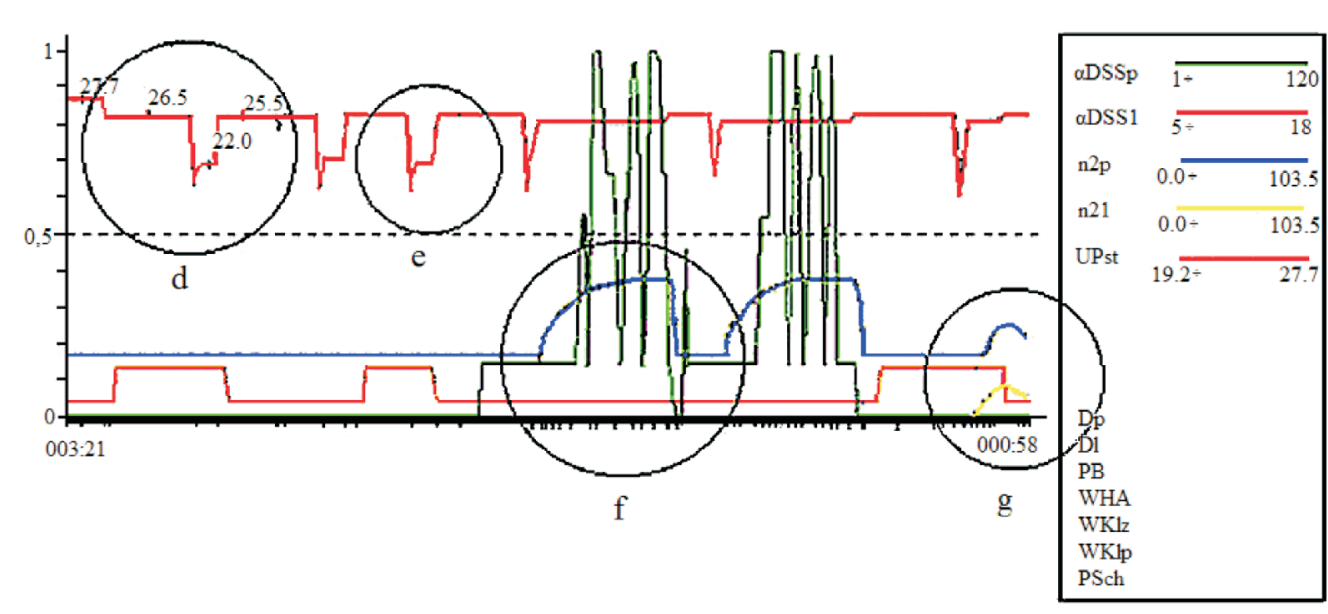

$\overline{\mathrm{G}}$ MIG-29 WYLOT: 0

ĆWICZENIE:0000

PRÓBA

Fig. 6. Increasing the MiG-29 engine speed

Rys. 6. Próba zwiększenia prędkości obrotowej silników samolotu MiG-29

The electrical connections were checked in the AES-ATC (Aggregate Transfer Case) harness. No circuits were broken, no short circuits or incorrect resistance of the insulation in individual parts of the harness were observed (from AES to ATC). The AES was renewed. The start aggregates were checked- the operation was correct. Upon renewal of the AES and a recheck, the attempt to increase the speed of the engines was retaken as shown in Fig. 6.

From the data presented in figure 6 the following concludes:

- The attempt to increase the left engine speed was performed twice during which a high voltage drop was observed (areas $\mathrm{d}$ and $\mathrm{e}-$ red line); left engine (yellow line) did not increase speed.

- The attempt to increase the right engine speed was performed twice- the attempt was successful (area $f$ - blue line).

- The final attempt included the increase in the speed of the left engine during which both engines began to rev up (area g).

From the analysis of the collected data, conclusions may be drawn that in a situation when both engines are started simultaneously, a very slow increase in the speed of crankshaft $\mathrm{n} 2$ to the values of $13 \%$ by approx. 25 seconds was observed, while during correct operation, only one engine is started and the process lasts for approx. 4-5 s. The changes of the DSS position angle shown in the figure (green line) result from the resolution of the recording system limited to 10 degrees. Such a signal is always neglected during the analysis and treated as a measurement uncertainty. The failure to start the left engine and a large voltage drop confirms that, in the ATC, clutches of both engines may have been engaged simultaneously, which resulted in a high load of the turbine starter. Since it was the left engine that the engineers attempted to start and the conditions for its start were fulfilled, it should be concluded that the clutch of the right engine was permanently engaged. It did not happen when only the right engine speed was increased. A slow start
Sprawdzono połączenie elektryczne w wiązce od APD do KSA ( $\mathrm{z}$ ros. Skrzynka Napędu Agregatów Samolotu). Nie stwierdzono przerw, zwarć ani niewłaściwej rezystancji izolacji w poszczególnych żyłach wiązki (od APD do KSA). Zabudowano nowe APD. Sprawdzono działanie agregatów rozruchu - działanie było prawidłowe. Po wymianie APD i sprawdzeniach powtórnie przeprowadzono próbę zwiększenia prędkości obrotowej silników, co

przedstawiono na rysunku 6.

$\mathrm{Z}$ danych przedstawionych na rysunku 6 wynika, że: - przeprowadzono dwukrotną próbę zwiększenia prędkości obrotowej lewego silnika, podczas której odnotowano duży spadek napięcia (obszary d i e - linia czerwona); lewy silnik (linia żółta) nie rozkręcał się,

- przeprowadzono dwukrotną próbę zwiększenia prędkości obrotowej prawego silnika - przebiegła prawidłowo (obszar f-linia niebieska),

- ostatnia próba obejmowała zwiększenia prędkości obrotowej lewego silnika, podczas której zaczęły rozkręcać się oba silniki (obszar g).

Z analizy zgromadzonych danych wynika, że w sytuacji uruchamiania dwóch silników jednocześnie odnotowano bardzo powolne zwiększanie się prędkości obrotowej wału n2 do wartości 13\% przez około 25 sekund, podczas gdy przy prawidłowym działaniu uruchamia się tylko jeden silnik i trwa to ok. 4-5 s. Pokazane na rysunku zmiany kąta położenia DSS (zielona linia) wynikają z czułości systemu rejestrującego wartości do 10 stopni. Sygnał taki jest zawsze bagatelizowany w analizie i traktowany jako niepewność pomiarowa. Nieuruchomienie lewego silnika oraz duży spadek napięcia mogą świadczyć, że były przyłączone jednocześnie dwa sprzęgła od silników w KSA, co dawało duże obciążenie turbostartera. Ponieważ miał być uruchamiany silnik lewy i były spełnione warunki do jego uruchomienia, należy wnioskować, że na stałe było załączone sprzęgło prawego silnika. Świadczyć o tym może to, że nie zauważono takich zjawisk przy zwiększeniu prędkości obrotowej tylko prawego silnika. Powolne uruchamianie dwóch silników jednocześnie potwierdza tę tezę. Przyczyną jednoczesnego uruchamiania dwóch silników była niesprawność bloku zaworów sterujących na KSA, albo sprzęgła w KSA przy uruchamianiu prawego silnika. Zostało to potwierdzone przez przedstawicieli WZL (Wojskowych Zakładów Lotniczych), którzy stwierdzili, że była to niesprawność bloku zaworów sterujących na KSA. 
of both engines at the same time confirms this assumption. The reason for the start of both engines at the same time was a malfunction of the ATC control valves or the clutch when the right engine was started. This was verified by the WZL (Wojskowe Zakłady Lotnicze, Military aviation works) technicians who confirmed that this was a malfunction of the block of control valves in ATC.

\section{Conclusions}

In the paper, the authors presented the applicable methodology used in case of a MiG-29 aircraft malfunction. The operation of the aircraft fitted with two engines is more complex than it is in the case of a single-engine aircraft. The presented examples of malfunctions indicate the complexity of the problems that the ground technicians and the pilots must deal with when operating a MiG-29. The knowledge on the discussed issues must be systematically expanded during numerous trainings and courses. Proper decisions of the technicians ensure not only the safety of the pilot and the aircraft but also prompt aircraft operational readiness. The pilots and ground technicians must be well familiarized with MiG29 engine start malfunction procedures.

\section{Podsumowanie}

W artykule przedstawiono obowiązujące metodologie postępowania po wykryciu awarii w samolocie MiG-29. Eksploatacja samolotu wyposażonego w dwa silniki jest trudniejsza niż samolotu jednosilnikowego. Przedstawione przykłady awarii wskazuja złożoność problemów, z jakimi musi zmagać się obsługa naziemna i pilot podczas eksploatacji samolotu MiG-29. Wiedza dotycząca omawianych zagadnień musi być systematycznie uzupełniana podczas licznych szkoleń i kursów. Od właściwego postępowania obsługi zależy nie tylko bezpieczeństwo pilota i samolotu, ale przede wszystkim minimalizacja czasu niezbędnego do przywrócenia użyteczności samolotu bojowego. Procedury postępowania w sytuacji awarii podczas uruchamiania silnika samolotu MiG-29 muszą być znane pilotowi i stanowią niezbędną wiedzę obsługi technicznej.

\section{Bibliography/Literatura}

[1] Balicki W. i in.: Lotnicze silniki turbinowe. Konstrukcja Eksploatacja - Diagnostyka. Biblioteka Naukowa Instytutu Lotnictwa, Warszawa 2012.

[2] Kowalski M.: Zagadnienia diagnostyki turbinowych silników lotniczych z wykorzystaniem danych z pokładowych rejestratorów lotu. Prace Naukowe Instytutu Technicznego Wojsk Lotniczych, z. nr 31, Warszawa 2012.

[3] Samolot MiG-29 - Instrukcja techniki pilotowania, WLOP 176/94, Poznań 1995.

[4] Samolot MiG-29 - Aerodynamika praktyczna, WLOP 48/91, Poznań 1992.

[5] Silnik turboodrzutowy RD-33 - opis techniczny i eksploatacja, tom 1, Poznań 1991.

[6] Silnik turboodrzutowy RD-33 - pis techniczny i eksploatacja, tom 2, Poznań 1992.

[7] Staniszewski R.: Sterowanie zespołów napędowych. WKŁ Warszawa 1998.
Jerzy Perczyński - Commander of Technical Services Team, 23 Airbase (23.BLT), Mińsk Mazowiecki. Ppłk mgr inż. Jerzy Perczyński - Commander of Technical Services Team, 23 Airbase (23.BLT), Mińsk Mazowiecki.

e-mail: 23blt@wp.mil.pl
[8] Szczeciński L.: Lotnicze silniki turbinowe. MON, Warszaw 1965.

[9] Szczeciński L.: Dwuwirnikowe, dwuprzepływowe lotnicze silniki turbinowe. WKŁ, Warszawa 1971.

[10] Wiatrek R.: Teoria silników lotniczych. WAT, Warszawa 1983.

[11] Żółtowski B.: Podstawy diagnostyki maszyn. Wydawnictwo Uczelniane Akademii Techniczno-Rolniczej, Bydgoszcz 1996.

Maciej Trelka - Commander of 23rd Airbase, Mińsk Mazowiecki.

Plk dypl. pil. inż. Maciej Trelka-dowódca 23. Bazy Lotnictwa Taktycznego w Mińsku Mazowieckim/ e-mail: 23blt@wp.mil.pl

Jarosław Bartoszewicz, DSc. DEng. - Assistant professor in the Chair of Thermal Engineering, Poznan University of Technology.

Dr hab. inż. Jarosław Bartoszewicz - adiunkt w Katedrze Techniki Cieplnej Politechniki Poznańskiej. e-mail: Jaroslaw.Bartoszewicz@put.poznan.pl 